\title{
Femur Mineral Density of Broilers with Femoral Degeneration Fed High Nutritional Density Diets
}

\author{
Densidad Mineral del Fémur de Pollos de Engorde con Degeneración \\ Femoral Alimentados con Dietas de Alta Densidad Nutricional
}

"I. C. L. Almeida Paz.; "A. A. Mendes; ${ }^{* *}$ M. R. F. B. Martins; ${ }^{* * *}$ B. C. S. Fernandes; *** I. C. L. Almeida; ${ }^{* * * *}$ E. L. Milbradt; ${ }^{* * *}$ A., Balog $\&^{* * * *}$ C. M. Komiyama.

ALMEIDA PAZ, I. C. L.; MENDES, A. A.; MARTINS, M. R. F. B.; FERNANDES, B. C. S. ; ALMEIDA, I. C. L.; MILBRADT, E. L.; BALOG, A. \& KOMIYAMA, C. M. Femur mineral density of broilers with femoral degeneration fed high nutritional density diets. Int. J. Morphol., 27(2):595-599, 2009.

SUMMARY: A study was carried out in the experimental facilities of FMVZ/UNESP-Botucatu, with the aim of following-up the development and the incidence of femoral degeneration (FD). A total of 305 one-day-old male broilers were housed in six pens of $5 \mathrm{~m}^{2}$ each. A completely randomized experimental design, with 3 treatments (T1-traditional nutritional density diet; T2-high nutritional density diet) of 3 replicates each was applied. Femoral head of the broilers were submitted to gross examination at 0, 7, 14, 21, 28, 35, and 42 days of aged. At 42 days of age, 60 birds ( 30 per treatment) were submitted to the Veterinary Hospital of FMVZ to determine bone mineral density by radiography. Birds were then sacrificed for gross examination of the legs, and FD scoring. Five legs per treatment within each FD score were submitted to computed tomography for femur head integrity and bone mineral density. Treatments did not influence FD incidence, and the first gross FD lesions appeared when birds were 28 days old. It was concluded that radiographic optical densitometry and computed tomography are efficient methods to evaluate femoral degeneration, and both techniques expressed the same profile. In addition, using radiographic optical densitometry and computed tomography, these results also allowed us to establish bone mineral density value ranges within each gross FD score. These finding may provide an excellent non-invasive tool to describe femoral degeneration.

KEY WORDS: Femur; Mineral density; Broilers; Femoral degeneration; High nutritional density diets.

\section{INTRODUCTION}

Pathologies affecting the limbs of animals raised under confined conditions are economically important, impairing performance animal welfare. Animals are unable to move properly and therefore to reach drinkers and feeder, with consequent reduction in feed and water intake, affecting their health and reproductive efficiency. It is well recognized that locomotion system pathologies are influenced by housing and management. In addition, the genetic improvement of poultry resulted in fast growth rates, which generally affects the mineral composition of bones and cartilages, thereby leading to locomotion impairment. Lean tissue maintenance requires more energy and oxygen than other tissues, and therefore, fast-growing birds are more susceptible to processes that cause tissue hypoxia (Gonzáles \& Macari, 2000).
According to Kealy (1987), femoral degeneration occurs in young animals, does not have a defined etiology, and can affect one or both legs, affecting not only femoral head, but also femoral neck. These changes can be diagnosed through X-ray images, which show low bone density of the trabecular bone arrangement, with consequent presentation of different bone deformities. In dogs, femoral degeneration is linked to feeding habits, and it is associated to high protein and low mineral intake.

Radiographic optical densitometry is based on the comparison of grey shades of the analyzed bone region with those of an aluminum scale with pre-defined density (phantom). This technique requires that the simultaneous exposure of phantom and bone segment to x-ray. The

* Universidade Estadual Paulista, Departamento de Produção Animal, Botucatu - SP, Brazil.

** Universidade Estadual Paulista, Departamento de Anatomia, Botucatu - SP, Brazil.

*** Universidade Estadual Paulista, Undergraduate student in Animal Science, Botucatu - SP, Brazil.

${ }^{* * * *}$ Universidade Estadual Paulista, Graduate student in Animal Science, Botucatu - SP, Brazil. 
radiographs are then scanned, generating bone mineral density values, which are expressed in millimeters of aluminum. Other technique used to determine bone quality of computed tomography. However, under situations as assessment of locomotion pathologies of live birds in broiler houses, gross examination is the recommended technique (Almeida Paz, 2008).

This experiment aimed at evaluating the effect of a hyper-protein and hyper-calorie diet on femoral mineral density and the incidence of femoral degeneration, as well as their possible relationship, in broilers.

\section{MATERIAL AND METHOD}

In this experiment, 305 one-day-old male broilers of a commercial strain were housed in an experimental poultry house of FMVZ-UNESP/Botucatu, at $5 \mathrm{birds} / \mathrm{m}^{2}$. The house was equipped with brooders, tube feeders, automatic bell drinkers, and fans, which were managed according to the birds' needs. A completely randomized experimental design, with two treatments with three replicates of 50 birds each, was applied. Birds were submitted to the following treatments: T1-traditional nutritional density diet, and T2high nutritional density diet (enriched diet). Feeds were divided in two phases: starter (0-21 days) and finisher (2242 days), as described in Table I.

Gross examination of the head of the femur. Femoral degeneration lesion development was followed-up by gross examination of the birds' femur head. Five samples were collected on day 0 of the experiment, i.e., before housing. Five birds were selected for specimen collection at 7, 14, 21,28 , and 35 days of age. At 42 days of age, five specimens of each macroscopic score were collected, summing 30 specimens. Bone specimens were examined at slaughter, when they were scored from 1 to 3 . Score 1 indicated no lesion, score 2 initial lesion, and score 3 severe lesion (Fig.1).

Bone mineral density analysis - radiographic optical density and computed tomography. At two 2 days of age, 30 birds per treatment were taken to the Veterinary Hospital of UNESP - Botucatu, where birds were submitted radiography to determine bone mineral density. The adopted technique was $30 \mathrm{kVp} \times 1.3 \mathrm{mAs}$ and a $90 \mathrm{~cm}$ focus-film clearance. The standardized reading region was the right femur head. Radiograph images were scanned and mean

Table I: Ingredient and nutrient compositions of the experimental diets.

\begin{tabular}{|c|c|c|c|c|}
\hline \multirow[b]{2}{*}{ Ingredients } & \multicolumn{2}{|c|}{ Treatment 1} & \multicolumn{2}{|c|}{ Treatment 2} \\
\hline & 0-21 days & 22-42 days & 0-14 days & 22-42 days \\
\hline Corn & 64.20 & 67.00 & 55.00 & 57.90 \\
\hline Soybean meal & 32.00 & 28.00 & 38.20 & 33.00 \\
\hline Dicalcium phosphate & 1.70 & 1.72 & 1.72 & 1.72 \\
\hline Limestone & 1.00 & 1.00 & 1.00 & 1.00 \\
\hline Soybean oil & - & 1.45 & 3.00 & 5.00 \\
\hline DL-methionine & 0.40 & 0.25 & 0.40 & 0.50 \\
\hline L-lysine & 0.20 & 0.10 & 0.20 & 0.40 \\
\hline Premix (vit+min) & 0.28 & 0.28 & 0.28 & 0.28 \\
\hline Salt & 0.20 & 0.20 & 0.20 & 0.20 \\
\hline Total & 100.0 & 100.0 & 100.0 & 100.0 \\
\hline \multicolumn{5}{|c|}{ Calculated composition } \\
\hline $\mathrm{ME} \mathrm{Kcal} / \mathrm{kg}$ & 2900 & 3000 & 3100 & 3300 \\
\hline $\mathrm{CP} \%$ & 20.00 & 18.00 & 23.00 & 21.00 \\
\hline $\mathrm{Ca} \%$ & 0.99 & 0.93 & 0.99 & 0.93 \\
\hline Avail. $\mathrm{P} \%$ & 0.47 & 0.44 & 0.47 & 0.44 \\
\hline Total Lys \% & 1.35 & 1.25 & 1.35 & 1.25 \\
\hline Total Met $\%$ & 0.51 & 0.48 & 0.51 & 0.48 \\
\hline
\end{tabular}

* Vitamin supplement (composition per kg product): Vit. A- 1,875,000 IU; Vit. D3- 625,000 IU; Vit. E- 3,750 mg; Vit. K3- 300 mg; Thiamin - 375 mg; Riboflavin - 1.375 mg; Pyridoxine - 500mg; Vit. B12- 3125 mg; Niacin - $8750 \mathrm{mg}$; calcium pantothenate - $2500 \mathrm{mg}$; folic acid - 150 mg; Biotin - 15 mg; Choline - 87.500 mg; Growth promoter - 10.000 mg; Coccidiostat- 25.000 mg; Antioxidant - $5.000 \mathrm{mg}$. Mineral supplement (composition per kg product):Fe - 50,000 mg; Cu - 70,000 mg; Mn - 60,000; Zn - 50,000 mg; I - 1,250 mg; Se - 200mg. 


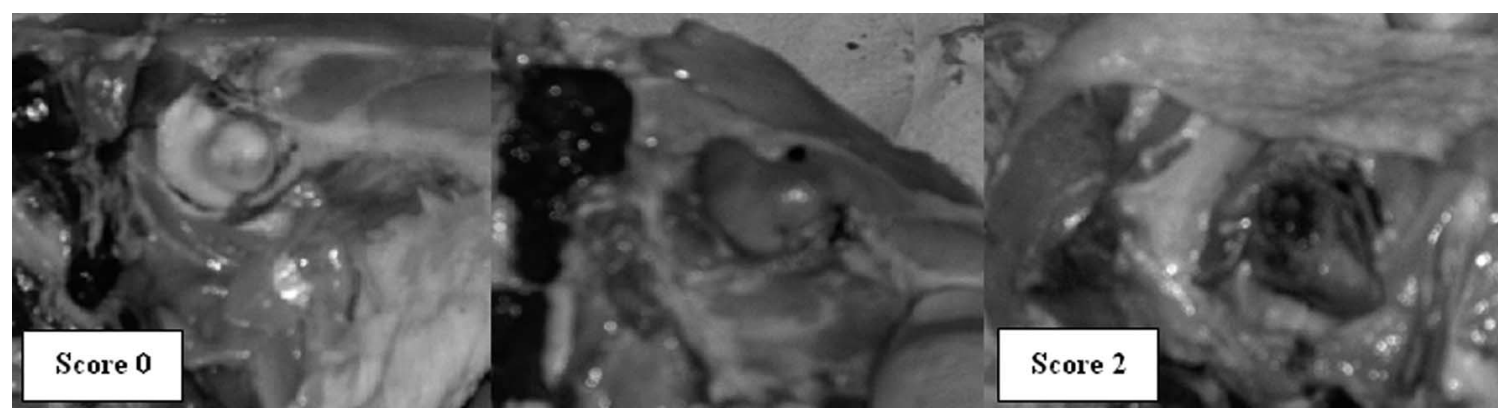

Fig. 1. Gross examination of the head of the femur.

radiograph optical densitometry values were calculated using a software program (Cromox ${ }^{\circledR}$ Athena-SIA). Readings used a $5 \mathrm{~mm}$ high and $20-30 \mathrm{~mm}$ wide window, depending on bone size (Fig. 2). After being submitted to radiography, birds were sacrificed, and five birds per gross score were selected. Bones were submitted to tomography according to a methodology adapted from Martinez-Cummer et al. (2006). Bone density of femur head and neck were assessed by comparing specimens with no lesions, with initial lesions, and with severe lesions, and classifying these lesions according to gross scores.

Statistical analysis. Data were submitted to analysis of variance using SAEG (1998) statistical package, and means were compared by the test of Tukey ( $95 \%$ probability). Femoral degeneration was characterized by calculating bone mineral density range, based on variance:

$$
\begin{aligned}
& \operatorname{IC}\left(\delta_{\tau}^{2}\right)=\frac{\varphi_{\tau}{\hat{\delta_{\tau}}}^{2}}{\chi^{2}(1-\alpha / 2)} \leq \delta_{\tau}^{2} \leq \frac{\varphi_{\tau}{\hat{\delta_{\tau}}}^{2}}{\chi^{2}(\alpha / 2)} \quad \hat{\boldsymbol{\delta}}_{\tau}^{2} \frac{\text { LSTreat }- \text { LSRes }}{\hat{\varphi}_{\tau}=\text { Degrees of Freedom of the Residue }} \\
& =\text { LSResidue }
\end{aligned}
$$

\section{RESULTS AND DISCUSSION}

Body weight and femoral degeneration incidence (FD) results of the studied broilers are shown in Table II. Body weight was not influenced by treatment, but it was different among the evaluated ages. The first gross FD lesions were observed at 28 days of age, and treatments affected its severity. At 28 days of age, the traditional diet promoted higher FD score, whereas the enriched diet resulted in higher FD score at 35 days of age, and no difference between treatments was observed at 42 days of age. These results are not consisted with the findings of Gonzales \& Mendonça Jr. (2006), who reported that metabolic diseases, including FD, can be induced by high density diets during the entire lifetime of broilers.

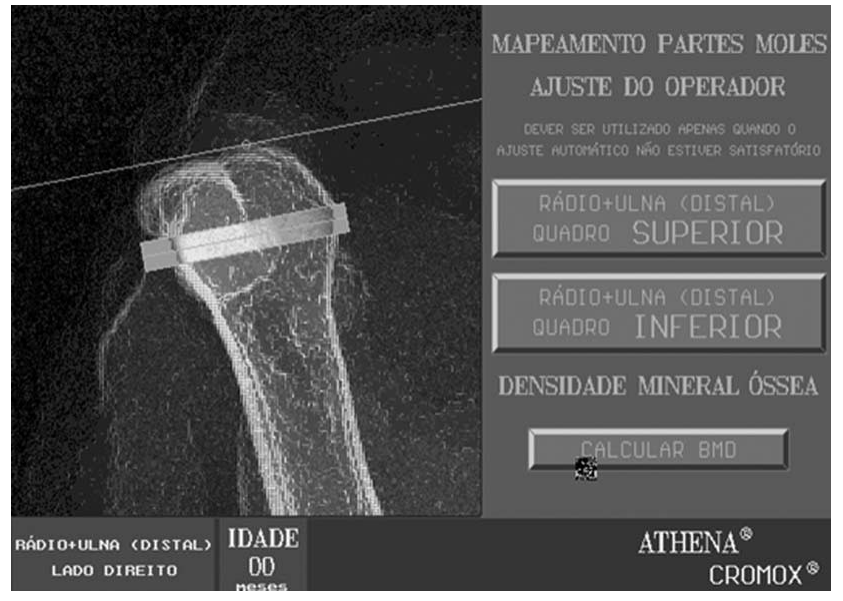

Fig. 2. Standardized region of bone mineral density readings of broiler femora.

No significant variation was observed in gross FD score among the studied ages or treatments. In addition, mean FD scores remained low, and were characterized by intermediate lesions.

Bone mineral density results of 42-day-old broilers, as determined by radiographic optical densitometry and computed tomography, are shown in Tables III and IV. There was a trend of reducing bone mineral density in T2 (enriched diet) according to the results using both techniques. These values were not statistically lower than those of birds fed diets containing traditionally used protein and energy levels. However, bone mineral density was different, using both radiographic optical density and computed tomography, as a function of gross FD scores. This is consistent with the data of Martinez-Cummer et. al., who used tomography to assess poultry bone quality, and reported that this is a good technique to predict bone mineral density.

Kealy obtained different results in dogs, which presented higher femoral degeneration scores when fed high protein diets. On the other hand, Edwards (2000) observed 
that the incidence of FD and other skeletal disorders may be higher when broilers are fed high metabolizable energy levels, whereas Mazzuco et al. (2005) did not find any effect of two different dietary energy levels on the bone mineral density of layers. The bone mineral density of $42-$ day-old broilers obtained in the present experiment with the radiographic optical density technique is very similar to those found in previous studies by our research group (Almeida Paz et al., 2007), of a bone mineral density value of $3.57 \mathrm{~mm}$ $\mathrm{Al}$ for healthy broiler femora.

Using radiographic optical densitometry and computed tomography, these results also allowed us to establish bone mineral density value ranges within each gross FD score for 42-day-old broilers, providing an excellent noninvasive tool to describe this pathology.

It was possible to infer that, independent of the diet, the incidence of femoral degeneration was high, with a mean value of $65 \%$ for 42 -day-old broilers. The techniques used to obtain bone mineral density in the present studyradiographic optical densitometry and computed tomography - may be used as good indicators of femoral degeneration lesion score.

Table II. Body weight and femoral degeneration incidence (FD) in broilers.

\begin{tabular}{cccccc}
\hline Age & Treatment & n. birds & Weight $(\mathrm{g})$ & Gross FD score & FD \% \\
\hline \multirow{3}{*}{28 days } & Traditional diet & 5 & 1619 & 1 & $20 \mathrm{c}$ \\
\cline { 2 - 6 } & Enriched diet & 5 & 1616 & 1 & $40 \mathrm{~b}$ \\
\cline { 2 - 6 } & Mean & 5 & $1618 \mathrm{c}$ & 1 & 30 \\
\hline \multirow{3}{*}{35 days } & Traditional diet & 5 & 2287 & 1 & $40 \mathrm{a}$ \\
\cline { 2 - 6 } & Enriched diet & 5 & 2174 & 1.5 & 50 \\
\hline \multirow{3}{*}{42 days } & Mean & 5 & $2176 \mathrm{~b}$ & 1.25 & $70 \mathrm{a}$ \\
\cline { 2 - 6 } & Traditional diet & 30 & 2359 & 1.29 & $60 \mathrm{a}$ \\
\cline { 2 - 6 } & Enriched diet & 30 & 2428 & 1.27 & 65 \\
\hline
\end{tabular}

Means followed by different letters in the same column are significantly different by Tukey's test $(\mathrm{p}<0.05)$.

Table III. Bone mineral density of 42-day-old broilers with or with no femoral degeneration.

\begin{tabular}{cccc}
\hline Gross FD score & Treatment & Radiographic optical density $(\mathrm{mm} \mathrm{Al})$ & Tomography $(\mathrm{Hu})$ \\
\hline \multirow{2}{*}{0} & Traditional diet & 3.94 & 266.00 \\
& High-density diet & 3.74 & 242.33 \\
\cline { 2 - 4 } & Mean & $3.84 \mathrm{c}$ & $254.16 \mathrm{c}$ \\
\hline \multirow{2}{*}{1} & Traditional diet & 2.93 & 199.33 \\
& High-density diet & 2.40 & 197.00 \\
\cline { 2 - 4 } & Mean & $2.66 \mathrm{~b}$ & $198.16 \mathrm{~b}$ \\
\hline \multirow{2}{*}{2} & Traditional diet & 1.99 & 189.00 \\
& High-density diet & 1.90 & 180.33 \\
\cline { 2 - 4 } & Mean & $1.95 \mathrm{a}$ & $184.66 \mathrm{a}$ \\
\hline
\end{tabular}

Means followed by different letters in the same column are significantly different by Tukey's test $(\mathrm{p}<0.05)$.

Table IV. Bone mineral density value range, as obtained by radiographic optical densitometry and computed tomography, as a function of gross FD score in 42-dayold broilers.

\begin{tabular}{ccc}
\hline Gross FD score & ROD $(\mathrm{mm} \mathrm{Al})$ & Tomography $(\mathrm{Hu})$ \\
\hline 0 & $3.68-4.21( \pm 0.30)^{*}$ & $242-266( \pm 0.08)^{*}$ \\
1 & $3.56-2.32( \pm 0.32)^{*}$ & $197-212( \pm 0.10)^{*}$ \\
2 & $2.40-1.53( \pm 0.30)^{*}$ & $191-179( \pm 0.17)^{*}$ \\
\hline
\end{tabular}

$* \mathrm{p}<0.05$. 
ALMEIDA PAZ, I. C. L.; MENDES, A. A.; MARTINS, M. R. F. B.; FERNANDES, B. C. S. ; ALMEIDA, I. C. L.; MILBRADT, E. L.; BALOG, A. \& KOMIYAMA, C. M. Densidad mineral del fémur de pollos de engorde con degeneración femoral alimentados con dietas de alta densidad nutricional. Int. J. Morphol., 27(2):595-599, 2009.

RESUMEN: Se realizó un estudio en las instalaciones experimentales de FMVZ/UNESP-Botucatu, con el objetivo de seguir el desarrollo y la incidencia de degeneración femoral en pollos. Se utilizaron 305 polluelos de un día, machos, distribuidos en seis corrales de $5 \mathrm{~m}^{2}$ cada uno. Se adoptó un delineamiento experimental totalmente al azar, con dos tratamientos de 3 repeticiones cada uno. Se alimentaron las aves del T1 con dietas con densidad nutricional convencional, mientras el T2 consistió de una dieta con alta densidad nutricional. Se realizaron análisis macroscópicos de la cabeza del fémur de aves de 0, 7, 14, 21, 28, 35 y 42 días de edad. A los 42 días de edad, se llevaron 60 aves (30 por tratamiento) al Hospital Veterinario de FMVZ, para hacer radiografías para el análisis de la densidad mineral ósea. Posteriormente, se sacrificaron los pollos para el análisis macroscópico de las piernas y se atribuyeron puntajes para DF. Se seleccionaron cinco muslos por tratamiento dentro de cada puntaje de DF, que fueron sometidas a tomografía para evaluación de la integridad y de la densidad ósea de la cabeza del fémur. Los tratamientos no tuvieron influencia en la incidencia de DF, y a partir de los 28 días de vida, las aves presentaron lesiones macroscópicas. Se estableció que la densitometría ósea y la tomografía son métodos eficaces para evaluar la DF, además que ambos expresan el mismo perfil. Por otra parte, se encontraron intervalos de valores para densidad mineral ósea obtenida por densitometría óptica radiográfica y por tomografía en función de los puntajes macroscópicos de DF. Esos hallazgos son una importante herramienta no invasiva para la caracterización de degeneración femoral.

PALABRAS CLAVE: Femur; Densidad mineral; Pollos de engorde; Degeneración femoral; Dieta de alta densidad nutricional.

\section{REFERENCES}

Almeida Paz, I. C. L.; Mendes, A. A.; Balog, A.; Almeida, I. C. L.; Vulcano, L. C. \& Komiyama, C. M. Caracterização da degeneração femoral em frangos de corte por meio da densidade mineral óssea. In: Conferência APINCO de Ciência e Tecnologia Avícolas. Santos: FACTA. Brazilian Jour. Poultry Sci., 2007.

Almeida Paz, I. C. L. Problemas locomotores e técnicas de mensuração. In: Conferencia APINCO 2008. Anais de Palestras, 265-9, 2008.

Edwards Jr., H. M. Nutrition and skeletal problems in poultry. Poultry Sci., 79(7):1018-23, 2000.

Gonzales, E. \& Macari, M. Enfermedades metabólicas em frangos de corte. In: Berchieri Jr., A; Macari, M. Doenças das Aves. Campinas, FACTA, 2000. pp.449-64.

Gonzáles, E. \& Mendoça Jr, C. X. Problemas locomotores em frangos de corte. VII Simpósio Brasil Sul de Avicultura. Chapecó, SC - Brasil. Anais., 2006. pp.79-94.

Kealy, J. K. Diagnostic radiology of the dog and cat. $1^{\mathrm{a}} \mathrm{Ed}$. Philadelphia. W. S. Saunders Company, 1987. p. 547.

Matínez-Cummer, M. A.; Heck, R. \& Leeson, S. Use of axial $\mathrm{X}$-ray microcomputed tomography to assess three-dimensional trabecular microarchitecture and bone mineral density in single comb white leghorn hens. Poultry Sci., 85(4):706-11, 2006.
SAEG (Sistema para análise estatística e genéticas). Manual de utilização do programa SAEG. Viçosa, UFV, 1998. p. 59.

Mazzuco, H.; Mc Murtry, J. P.; Kuo, A.Y. \& Hester, P. The effect of pre- and postmolt diets high in n-3 fatty acids and molt programs on skeletal integrity and insulin-like growth factor-I of white leghorns. Poultry Sci., 84:173549, 2005.

Correspondence to:

Dr. I. C. L. Almeida Paz.

Universidade Estadual Paulista

Departamento de Produção Animal,

Botucatu - SP

BRAZIL

E-mail: ibiara@fca.unesp.br

Prof. Dr. Márcia Regina Fernandes Boaro Martins E-mail: ibiara@ibb.unesp.br

Received: $28-10-2008$

Accepted: 15-04-2009 
